\title{
Performance Analysis of Biology Education under the Implementation of Lower Secondary School Biology-Competence-Based Curriculum: Policy Implications
}

\author{
Emmanuel Bizimana ${ }^{1 *}$, Dieudonné Mutangana ${ }^{2}$, Adrian Mwesigye ${ }^{3}$
}

${ }^{1}$ College of Education-ACEITLMS, University of Rwanda, RWANDA

${ }^{2}$ College of Science and Technology, University of Rwanda, RWANDA

${ }^{3}$ Mbarara University of Science and Technology, UGANDA

*Corresponding Author: emmanuelbizimana68@gmail.com

Citation: Bizimana, E., Mutangana, D., \& Mwesigye, A. (2022). Performance analysis of biology education under the implementation of lower secondary school biology- competence-based curriculum: Policy implications. Interdisciplinary Journal of Environmental and Science Education, 18(1), e2259. https://doi.org/10.21601/ijese/11331

ARTICLE INFO ABSTRACT

Received: $\quad$ Education in general and science particularly are believed to promote the country's development. To 4 December 2020 this end, the government of Rwanda and its stakeholders in education have put efforts in place expected to improve the teaching and learning process of science and performance as well. Some of these efforts include among others the adoption of a Competence-Based Curriculum. This study Accepted: $\quad$ analyzed the performance of students in biology among public lower secondary schools based on 5 February 2021 gender, type, and school location in Nyamagabe district, Rwanda during the implementation of BCBC. An ex-post facto research design was adopted to analyze biology grade scores of 3,129 students, who sat for the 2018 Ordinary Level Biology National Examination. Descriptive statistics and an Independent Sample t-test were used to analyze data. Results evidenced that students' performance in Biology was low (49\% failed). The study found significant differences in students' performance based on gender $(t=-11.59, p<0.05)$, type of school $(t=-19,46, p<0.05)$ and school location $(t=-6.36$, $\mathrm{p}<0.5)$. The study concluded that despite the introduction of the Biology Competence-Based Curriculum (BCBC), the students' performance in biology is still not encouraging. The gender, type of school, and school location affect students' academic performance in Biology. The findings provide the government and its stakeholders with insights on the need to encourage female students to study Biology, fund and equip day and rural secondary schools with both human and instructional resources to improve teaching and learning Biology as well as students' performance in the subject.

Keywords: academic performance, biology, boarding school, day school, gender, national examination, school location

\section{INTRODUCTION}

Education has been recognized as an investment as well as a key to promoting and achieving rapid economic, social, political, technological, and scientific development of both an individual and a country. On this basis, Bichi et al. (2019) stated that education is a viable tool that guarantees economic growth, environmental protection, social, scientific, and technological development, and employment opportunities in an equal manner. Equally, education is essential in the reduction of poverty, increases the opportunity for getting new jobs as well as accelerates sustainable development (UNESCO, 2014). This suggests that the quantity and the quality of education received by people determine the development of their nation.

Recognizing the inestimable value of education for its citizens, the government of Rwanda considers education as an instrument par excellence for achieving its developmental policies. Thus, in 2007 started implementing the fee-free Nine Years Basic Education (9YBE). In this regard, the free basic education was

Copyright (C) 2022 by Author/s and Licensed by Veritas Publications Ltd., UK. This is an open access article distributed under the Creative Commons Attribution License which permits unrestricted use, distribution, and reproduction in any medium, provided the original work is properly cited. 
expanded from Primary 1 (P1) to lower secondary education (the first three years). In the same vision, in 2012, free basic education was prolonged to 12 years (Nkurunziza et al., 2012). The objectives of the free basic education Policy were, among others, to enhance access to primary and secondary schools by making secondary school education affordable, available, to improve equity and gender parity in the provision of both primary and secondary education to Rwandans (Ministry of Education [MINEDUC], 2007).

Besides, to improve the quality of education and to stimulate students' interest in sciences including Biology, Rwanda has embarked on curriculum reform since 2015 (Rwanda Education Board [REB], 2015). This reform decided to shift from Knowledge-Based Curriculum (KBC) to Competence-Based Curriculum (CBC). The purpose was to put emphasis on the need of students by providing them with the knowledge, skills, attitudes, and values required for competing in both local, national, and regional labor-market (Mbarushimana \& Kuboja, 2016; REB, 2015;). While KBC emphasized the grasp of knowledge by emphasizing knowledge acquisition, $\mathrm{CBC}$ emphasizes knowledge creation and application (REB, 2015; Ngendahayo \& Askell-Williams, 2016). Moreover, the $\mathrm{KBC}$ was rooted in traditional teaching and learning approaches such as lecture and chalk and talk, resulting in rote memorization and acquisition of fractural knowledge. According to REB (2015), the KBC was ineffective as the graduates failed to demonstrate the skills and competences that completely addressed local, regional and global market demands.

The 2015 Competence-Based Curriculum in contrast to $\mathrm{KBC}$, promotes cooperative, inclusive, and active learning through a learner-centered teaching approach (REB, 2015). The teacher is required to facilitate learning by involving students in learning activities that promote the development of critical thinking and other twenty-first-century skills like problem-solving skills, communication, and collaboration. Within this new paradigm of teaching and learning, students are encouraged to actively engage in learning activities hence they gain knowledge and skills to apply in everyday life (REB, 2015).

Rwandan competence-based Biology curriculum aims at stimulating students and creating sustainable interest in biology; developing abilities and skills that are deemed essential to be used in everyday life. Furthermore, it aims at promoting good attitudes, values, and awareness of environment conservation in learners and enhancing experimenting with a range of scientific and technological tools to draw an appropriate conclusion (REB, 2015).

In lower secondary level (senior one, senior two, and senior three) of Rwandan secondary schools, Biology is taught as a core subject. Due to the reform, many changes occurred not only in the content to be taught but also in the teaching approaches. During the review, new topics were added and many topics from the old curriculum were retained, but are now expanded so that their value and importance are accentuated to meet CBC objectives. For instance, while in the old curriculum senior one, the content to be covered was organized in four chapters that are: living things, plant, animals, and the human body (National Curriculum Development Centre [NCDC], 2006), the current senior one curriculum is made up 14 units. Generally, the current ordinary level Biology competence-based curriculum is made up of 52 units, with 14 units in senior one, 16 units in senior two, and 22 units in senior three (REB, 2015).

Regarding methodology, it is stated in the lower secondary school Biology syllabus that the success of teaching and learning of Biology subject can be achieved by maximum participation of the learners in the teaching and learning process. In this regard, learners are expected to conduct experiments, study tours, fieldwork, group work, individual work, and project work to enhance the learning of Biology as well as to promote critical thinking (REB, 2015).

The issues regarding assessment were actualized also in CBC. In CBC, the assessment should focus mainly on competences developed by students rather not on the mastery of the concepts learned (Mbarushimana \&Kuboja, 2016). It takes the form of formative (assessment for learning) and summative assessment (assessment of learning) and forms an integral part of the process of competence development. Besides, the assessment method should probe students' understanding, reasoning, and critical thinking rather than their ability to return memorized facts (REB, 2015). To this effect, the assessment methods should include a portfolio, projects, oral presentation, self, and peer assessment, interviews, and conferencing, tests, practical tasks to demonstrate performance skills, essays/reports among others (REB, 2015).

Secondary school education in Rwanda refers to the education which learners undertake after completing primary education. It includes lower secondary education (ordinary/lower level) which spans senior one to senior three (S1-S3), and the upper secondary level starts from senior four to six (S4-S6). Lower secondary education is a very critical level of the whole students' further education. This is because apart from serving as the link between primary and upper secondary education, it provides opportunities for children to acquire supplementary skills and knowledge beyond the primary level. Besides, it is also considered as the entry to upper secondary as well as a cycle that provides essential knowledge and skills for those who continue to the technical formation (World Bank, 2011). Therefore, it the bedrock on which the post-lower secondary education is built as it lays the foundation of whatever a child will learn in further education. The lower secondary education ends by Ordinary Level Leaving 
National Examination, which is used as a tool for the selection of students for boarding schools at the upper secondary level. It is conducted annually at the same time, and each candidate is tested in nine compulsory subjects (REB, 2013).

Biology is part of the national examinable subject. It is a science subject that studies living things, both plants and animals, and their vital functions. The study of biology enables one to understand himself/herself and the surrounding environment. It is a subject that endeavors to understand the essential biological processes that take place within living beings, for example, digestion, respiration, circulation, excretion, and gaseous exchange. Besides, the knowledge and skills learned from ordinary level biology contents are the prerequisite of biology knowledge and skills to be studied in biology-related combinations at the upper secondary level and in some required fields such as medicine, pharmacy, nursing, microbiology, dentistry, and agriculture among others at tertiary education level (REB, 2015). Therefore, it is one of the important areas of study in the life course of an individual.

The National Ordinary Level Examination for Biology carries 100 marks and is composed of three sections such as Section A (55 marks), Section B (30 marks), and section C (15 marks). The document review revealed that Section A is always allotted 55 marks from 2002 up to 2019. It generally consists of mostly two-page questions. Some of its questions require students to answer either in their own words (for 2015) or they are true or false questions $(2017,2019)$ or matching types of answer questions (for 2018). It also sometimes provides a list of words from which the candidate is requested to choose the correct word to fill in the gaps (for 2011, 2014, and 2017).

Concerning section B, candidates are given several questions (usually five) from which they have to choose three for 30 marks. The following are some of the questions:

1. a) Define "transpiration"

b) How do plants benefit from transpiration?

In section $\mathrm{C}$, candidates are provided with one compulsory question for 15 marks. This brief overview indicates that the structure of the National Ordinary Level Examinations for Biology changed neither in KBC nor in CBC. Besides, a critical look at these questions revealed that they do not either encourage learners to use their own words in formulating the answers or think from various perspectives. Therefore, they only evaluate learners' knowledge and comprehension instead of their understanding and critical thinking. This is in line with Biggs (1996) who argues that such types of questions and proposed answers are unlikely to elicit a high level of engagement from learners. To this effect, allowing learners to answer using their own words as required by $\mathrm{CBC}$ could have been a better alternative.
In terms of ordinary level national examination management, it is the panacea of the REB established by law No. 44/2010 of December 2010. Hence, it is up to the REB to coordinate all activities related to National Examination conduct, setting candidates' eligibility criteria as well as fixing the subjects to be evaluated. The same institution is responsible for announcing the results and granting certificates (REB, 2013). Grading students in the lower secondary school leaving examination is such that the scores are grouped into four scales where the Distinction is represented by grades 1 and 2. The credit is represented by grades 3 to 6 . The passing is represented by grades 7 and 8 , and the failing grade is represented by 9 (REB, 2013).

Consequently, for any subject exam, a student may get a grade between 1 (best) and 9 (worst). This implies that the lower the grade level, the higher the academic performance score students have. In admitting students in the upper secondary level of their schools of choice, the REB uses average grade scores. This means that the more a student performs with the first best grades, the more is qualified for boarding school admission, and the more a student performs poorly with the worst grades, the more is qualified to day school. Therefore, the ordinary level leaving examination is highly competitive as the best grade scores are required for admission into public and government-subsidized desirable boarding schools with limited places. The remaining students are admitted in private schools or Twelve Year Basic Education (12YBE) schools in a general advanced level known as day schools while others join Technical Vocational Education Training (TVET) schools (MINEDUC, 2012).

Despite the prime position Biology occupies in the Rwandan education system, and numerous advantages derivable from the study of Biology for both individuals and nation, it is worthless to note that students are still performing poorly in Biology compared to the other science subjects especially in National Examinations (MINEDUC, 2012). Besides, this poor performance cuts across almost all districts in Rwanda. This is attested by the results of the Ordinary Level National Examinations over the past years. For instance, Ntawiha (2016) found that Biology (mean=3.8) was less performed in S3NE compared to Chemistry (mean=4.9) and Physics (mean=5.6) among public secondary schools in the Nyarugenge and Nyamasheke districts of Rwanda.

The low students' academic performance in Biology Ordinary Level National Examination has prevented the majority of students to be admitted into the most desirable boarding schools. It has also aborted their ambition to study biology-related combinations at the advanced secondary level. This ends up by reducing the number of students to be enrolled in tertiary education in science-related courses. This situation has raised problems with much attention from different educational stakeholders as they agree that the input in education has 
not yielded the desired outcomes. This is so because, the academic performance at all levels of education in Rwanda is regarded in terms of the passes in the National Examinations; the number of students who obtained certificates as well as the number of students who got admission to the further educational levels (Harerimana et al., 2017).

Various studies have attached poor students' academic performance in Rwanda to several factors. For instance, Ndihokubwayo (2017) concluded that the inadequacy of laboratory equipment contributes to poor quality teaching and learning. Also, Nzabalirwa and Nkiliye (2012); Nizeyimana and Nkiliye (2015), Rubagiza et al. (2016) postulated that lack of sufficient instructional materials, untrained and demotivated teachers are among the factors that have lowered the quality of teaching and therefore students' performance, especially in most rural 12 Year Basic secondary schools in Rwanda. Moreover, researchers like Lackamp (2016), Bagabe (2015) Pearson (2014), Sibomana (2014) reported the medium of instruction as a driving factor for lower students' performance. Furthermore, the report and other research studies (World Bank, 2011; Parajuli \& Thapa, 2017; Adebisi et al., 2017; Nsengimana et al., (2017) declared types of school (boarding or day), gender, school location among others as factors affecting students' academic performance.

Gender, as a factor in academic performance, has been a concern of different researchers over the years. However, their findings and conclusions have moved with time with differing results. For instance, Nnenna and Adukwu (2018) and Kashu (2014) reported that boys did better than girls. On the other hand, researchers like Bichi et al. (2019), Bozdoğan et al. (2014), Okorie and Ezeh (2016) in their separate studies reported that girls outperformed boys in biology. However, Ngozi et al. (2018), Ogbianigene (2014), Olasehinde and Olatoye (2014) observed that boys and girls academically performed equally overall science achievement (Biology, Chemistry, and Physics).

From all the aforementioned empirical studies, it is apparent that gender is an essential determinant of learners' performance in various subjects. However, studies on the influence of gender on academic performance remain inconclusive. Besides, most of these reviewed studies were conducted in foreign countries. Hence, this study sought to analyze the performance of male and female students in the Biology National Examination in lower secondary schools in Nyamagabe district, Rwanda.

Together with gender, the location of the school may also affect the performance of students in science, Biology included. According to Okorie and Ezeh (2016), school location refers to the place (urban or rural) in which the school is placed. School location may be categorized into urban and rural. This categorization is based on the presence of infrastructural facilities like water, electricity, hospitals, and educational institutions. Urban schools are likely to have more infrastructure than those in rural areas. Therefore, depending on the availability of the facilities, the school location implies an urban-rural setting. To Ellah and Ita (2017), urban schools are mainly found within the towns and cities, and rural schools are located in the villages or semi-urban areas.

In Rwanda, Rubagiza et al. (2016), Harerimana et al. (2017) in their studies indicated that teachers in urban schools were more provided with teaching and learning materials like internet facilities, books, and social amenities like electricity, computer, internet than teachers in rural schools. Besides, urban school teachers receive salary top-up from the parents' contribution in addition to government remuneration. This results in qualified teachers' refusal to enthusiastically posting to rural locations, and as a result, affects students' performance (Tumwebaze, 2016). However, rural school teachers with low pay, are likely not to have a top-up from parents of learners. Besides, their opportunities to earn additional income in rural areas are mainly less (Bennell \& Ntagaramba, 2008; Rubagiza et al., 2016).

Ellah and Ita (2017) stated that the location of a school determines to a large extent, the level of students' performance in biology. This implies that the school location can affect students' learning outcomes. In this regard, Nnenna and Adukwu (2018), Olusola and Omotade (2014), Umar (2017), Olutola (2017), in their separate studies in Nigeria found that the urban students achieved higher than rural students in science subjects. Similarly, Alordiah et al. (2015) found that students from urban schools performed better than rural school students in mathematics and basic science respectively.

On the other hand, in Nigeria Awodun and Oyeniyi (2018) found out that the school location does not influence students' performance in Basic science. Similarly, Mafulul (2012) observed that students from urban schools and those from rural schools did not differ in their mean performance scores when they were exposed to learning physics through Computer-Assisted Instruction (CAI).

To the above review, various studies indicate that the influence of school location on students' academic performance is not the same. Some researchers stated that students from urban schools perform better than students from rural areas, others pointed out that rural school students perform better than their urban counterparts, while other researchers maintained that school location does not influence students' academic performance. To this effect, the present study adds to the debate because studies on the influence of the location of the school on students' academic performance are still inconclusive.

The type of school attended, as it has been identified by several researchers seems to be also another influencing factor in students' academic performance. 
This is so because the type of school is one of the critical factors considered in the admission of students after national exams. Therefore, it undoubtedly plays a specific role in students' performance. The type of school may be day or boarding schools. According to Adebisi et al. (2017), boarding schools are the schools where students are provided with accommodation within the school. It is a residential school where students live and study during the school year. Day schools, on the other hand, are the schools where all the students go for studies and return to their homes (Adebisi et al., 2017). The literature revealed that boarding schools gradually provide quality education than day schools that can positively influence academic performance. This is because, according to Atieno (2017), Adebisi et al. (2017), students in boarding schools have ample time to study, read, and face fewer distractions, access easily learning facilities, thus consequently outperform their counterparts in day schools. Similarly, Mbonyumuvunyi (2015), Muhire (2015) concluded that boarding schools performed better than day schools in Rwandan secondary schools. The authors maintained that boarding schools are well-staffed and with good facilities than day schools. Hence, these factors induce better performance in the boarding than in the day schools.

Likewise, Adebisi et al. (2017) observed that Nigerian students in boarding schools scored better results than students in day schools in biology. Similarly, Adetunde and Asare (2009) in Nigeria found a significant difference between a student who has been a boarding student and a day student. The study of Ogechukwu and Chika (2018) in Nigeria revealed that boarding students academically achieve better than day students. They further explained the poor performance of students in day schools could be explained by the fact that they are distracted at home, unlike boarding school students who are under the control of the school authorities and teachers for their study. Bard (2011) corroborated this viewpoint when he opined that students in day schools are distracted at home, unlike boarding students that are kept in control during their studies.

It is on the premises mentioned above that this study was undertaken to empirically analyze the academic performance of students in Biology National Examination in lower secondary schools in Nyamagabe District, Rwanda after three years of implementation of Biology Competence-Based Curriculum. Specifically, the study aimed to ascertain the difference in the students' academic performance in biology based on gender, type of school, and school location.

\section{Research Questions}

This study analyzed the results of students in Biology in the Ordinary National Examination to find the answer to the following research questions:
1. What inferences can be deduced about the academic performance of students in the Biology National Examination 2018?

2. Is the academic performance in Biology National Examination governed by variables of influence as gender, type of school, and location of the school?

\section{Research Hypotheses}

The following null hypotheses were tested at 0.05 level of significance.

1. There is no significant difference in the performance of male and female students in the Biology National Examination.

2. There is no significant difference in the students' performance in the Biology National Examination based on the type of school.

3. There is no significant difference in students' performance in Biology National Examination based on school location.

\section{METHOD}

The design adopted for this study was an ex-post facto research design type. In this type of research, the researcher does not have any control over the independent variables since their manifestations have already occurred (Creswell, 2014). The researchers were interested in examining the phenomena under investigation and data were collected after the phenomena had taken place. In this regard, data involved in this study (lower secondary National Examination results) were observed and used as found in their natural state. Therefore, there was no treatment and manipulation of the subjects rather, the study involved the collection of data from records.

The population for this study comprised of all lower secondary school students who appeared for Ordinary Level National Exams in Nyamagabe district, with a total of 3,129 in the 2018 academic year (Table 1). Purposive sampling was used to collect National examination results in Biology, while a universal sampling technique was used to select the schools. The sample comprised all students from the selected schools. The inclusion of all students was to avoid bias in the selection of students and scores from each selected school (Adebisi, Nkechi \& Danmole, 2017). The available results of students in Biology, such as grade scores in the 2018 Ordinary National Biology Examination were used as measures of academic performance. The data were collected from the REB reports of National Examination 2018 in the District Director of Education (DDE) office in Nyamagabe district, Rwanda. Collected data were analyzed using SPSS version 21.0. Frequency and percentage were used to answer the research questions while the Independent Sample T-Test was used to test the hypothesis at a 0.05 level of significance. The tabular model was used to present the study findings. 
Table 1. Sample of students used in the study

\begin{tabular}{llcc}
\hline Variable & & No. of Students & Percentage \\
\hline Gender & Male & 1,415 & 45.2 \\
& Female & 1,714 & 54.8 \\
Type of school & Total & 3,129 & 100.0 \\
& Boarding & 615 & 19.7 \\
\multirow{2}{*}{ School location } & Day & 2,514 & 80.3 \\
& Total & 3,129 & 100.0 \\
& Urban & 639 & 20.4 \\
& Rural & 2,490 & 79.6 \\
& Total & 3,129 & 100.0 \\
\hline
\end{tabular}

\section{RESULTS AND DISCUSSION}

The results of this study are presented in the forms of descriptive and inferential statistics. Similarly, the findings are discussed with the findings of other related studies.

\section{Academic Performance of Students in Biology}

To determine the academic performance of students in Biology, grade scores, frequency, and percentage of students' performance were computed and presented in Table 2.

Table 2 indicates that almost half (49\%) of the sample demonstrated poor performance. On the rest of the sample, the largest proportion (36\%) lies in the 3-6 range. However, the distribution is again skewed on the poor end with almost a fifth (13\%) of the remaining proportion $(51 \%)$ falling in the grade 7-8 range. This trend calls for seeking reasons for such low performance. The poor performance of students in Biology may be explained in the context of the fact that most secondary school teachers are still predominantly using teachercentered related teaching techniques like lecturing (Byusa et al., 2020; Nsengimana, Habimana, \& Mutarutinya, 2017), the insufficiency of instructional materials, and lack of science laboratory equipment in many schools in Rwanda (Ndihokubwayo, 2017; Rubagiza et al., 2016; Nizeyimana \& Nkiriye, 2015). Consequently, once students are taught principally science concepts under ineffective and inappropriate teaching and learning strategy as well as the teaching and learning resources, there might be students' inadequate understanding of the concepts taught. Hence, this leads students to memorize facts only for school examination and thereafter promptly forget what they have learned, which may, in turn, explain the low achievement in Biology in National Examinations (Orbanić, Dimec, \& Cencič, 2016).

\section{Academic Performance of Students in Biology by Gender}

Grade scores obtained by male and female students in biology were analyzed using frequency and percentages to determine the academic performance of students in biology by gender. Table 3 below shows the findings.

According to the passing grades, Table 3 shows that on average, $17.7 \%$ of male students failed while $31.3 \%$ of female students failed. This means that a high percentage of female students failed compared to male students. The finding agrees with the reports of World Bank (2011) and MINEDUC (2018) where it was

Table 2. Descriptive statistics on students' academic performance in biology

\begin{tabular}{lll}
\hline Grade Score Range & Frequency & Percent \\
\hline $1-2$ & 47 & 1.5 \\
$3-6$ & 1,133 & 36.2 \\
$7-8$ & 416 & 13.3 \\
9 & 1,533 & 49.0 \\
Total & 3,129 & 100.0 \\
\hline
\end{tabular}

Table 3. Performance of students in biology by gender

\begin{tabular}{llllll}
\hline Gender & & \multicolumn{3}{l}{ Performance by Grade Score Range } \\
\cline { 3 - 6 } Male & & $1-2$ & $3-6$ & $7-8$ & 9 \\
\cline { 3 - 6 } & Frequency & 33 & 651 & 176 & 555 \\
\multirow{2}{*}{ Female } & Percentage & $1.1 \%$ & $20.8 \%$ & $5.6 \%$ & $17.7 \%$ \\
& Frequency & 14 & 482 & 240 & 978 \\
\multirow{2}{*}{ Total } & Percentage & $0.4 \%$ & $15.4 \%$ & $7.7 \%$ & $31.3 \%$ \\
& Frequency & 47 & 1,133 & 416 & 1,533 \\
& Percentage & $1.5 \%$ & $36.2 \%$ & $13.3 \%$ & $49.0 \%$ \\
\hline
\end{tabular}


Table 4. Performance of students in biology by type of school

\begin{tabular}{llllll}
\hline Type of school & & \multicolumn{4}{l}{ Performance by Grade Score Range } \\
\cline { 3 - 6 } & & $1-2$ & $3-6$ & $7-8$ & 96 \\
\hline \multirow{2}{*}{ Boarding } & Frequency & 32 & 395 & $2.1 \%$ & $3.9 \%$ \\
& Percentage & $1.0 \%$ & $12.6 \%$ & 350 & 1411 \\
\multirow{2}{*}{ Day } & Frequency & 15 & 738 & $11.2 \%$ & $45.1 \%$ \\
\multirow{2}{*}{ Total } & Percentage & $0.5 \%$ & $23.6 \%$ & 416 & 1533 \\
& Frequency & 47 & 1,133 & $13.3 \%$ & $49.0 \%$ \\
\hline
\end{tabular}

Table 5. Performance of students in biology by school location

\begin{tabular}{|c|c|c|c|c|c|}
\hline \multirow[t]{2}{*}{ School location } & & \multicolumn{4}{|c|}{ Performance by Grade Score Range } \\
\hline & & $1-2$ & $3-6$ & $7-8$ & 9 \\
\hline \multirow{2}{*}{ Urban } & Frequency & 25 & 279 & 79 & 256 \\
\hline & Percentage & $0.8 \%$ & $8.9 \%$ & $2.5 \%$ & $8.2 \%$ \\
\hline \multirow{2}{*}{ Rural } & Frequency & 22 & 854 & 337 & 1277 \\
\hline & Percentage & $0.7 \%$ & $27.3 \%$ & $10.8 \%$ & $40.8 \%$ \\
\hline \multirow{2}{*}{ Total } & Frequency & 47 & 1133 & 416 & 1533 \\
\hline & Percentage & $1.5 \%$ & $36.2 \%$ & $13.3 \%$ & $49.0 \%$ \\
\hline
\end{tabular}

indicated that female students did not perform well compared to their male counterparts in the Ordinary Level National Examination. The finding also concurs with the data published by Nizeyimana and Nkiliye (2015), according to which girls are less performing in Basic Education in Gicumbi, Kicukiro, and Rwamagana districts of Rwanda. The low performance of girl students compared to boys is mainly due to the barriers they encounter at home that prevent them from learning effectively (Rwegasira, 2017; Nizeyimana \& Nkiliye, 2015; Bizimana, 2011).

\section{Academic Performance of Students in Biology by Type of School}

Grade scores obtained by students from boarding and day schools were analyzed using frequency and percentages to determine the academic performance of students in biology by type of school. Table 4 shows the findings. Based on the pass grade score, Table 4 shows that on average, $3.9 \%$ of boarding school students failed while $45.1 \%$ of day students failed. This indicates that the academic performance of students from day schools in the Biology National Examination was low compared to that of boarding school students. This finding is not far from the World Bank (2011)'s report, Mbonyumuvunyi (2015), Muhire (2015)'s research findings, which concluded that boarding schools performed better than day schools.

\section{Academic Performance of Students in Biology by School Location}

Grade scores obtained by students from urban and rural schools were collected and analyzed using frequency and percentages (Table 5). Referring to the pass grade score, the findings indicate that on average, $8.2 \%$ of boarding students failed while $40.8 \%$ of day students failed. This means that the performance of students from rural schools was low compared to students from urban schools. The finding is in line with Umar (2017) who found a disparity in the academic performance of students in the West Africa Examination Council at which, urban students performed better than rural school students. The author further explains that most rural schools lack adequate facilities for teaching and learning biology.

Another explanation for the poor performance of students from rural schools may be that most students are not motivated to study in rural schools. This is in line with Nizeyiman and Nkiliye (2015), Mbonyumuvunyi (2015) who found in their different studies that lack of students' motivation to study in rural schools in Rwanda was among of crucial causes responsible for the poor academic performance of students admitted in rural secondary schools.

To find out if the difference in the performance of male and female students in the Biology National Examination is significant, the average biology grade scores of male and female students were used to conduct a test of difference. The independent t-test was used at a significance level of 0.05 as shown in Table 6 below.

Table 6 shows that male students on the grade score average performed than the female students $(t=1.59, \mathrm{p}=$ $.000<0.05)$. There is a significant difference between the academic performance of male and female students in biology. This difference was in favor of male students.

This finding is consistent with that of Kashu (2014), Nnenna, and Adukwu (2018). However, the finding is in contrast with that of Bozdoğan et al. (2014), Okorie and Ezeh (2016), Bichi et al., (2019) who found that female students performed better than male students in science. Besides, the finding contradicts that of Olasehinde and Olatoye (2014), Ngozi et al. (2018), Joseph and John (20 15), Ogbianigene (2014), Olasehinde and Olatoye (2014) who affirmed that gender differences do not affect students' academic achievement in the science subjects. 
Table 6. T-test on difference in academic performance in biology based on gender

\begin{tabular}{|c|c|c|c|c|c|c|}
\hline Group & $\begin{array}{l}\text { Grade } \\
\text { Average }\end{array}$ & Score & SD & $\mathrm{df}$ & t-cal. & Sig. of t-value \\
\hline Male & 2.88 & & .96 & 3127 & -11.59 & $0.00(\mathrm{~s})$ \\
\hline Female & 3.27 & & .90 & & & \\
\hline
\end{tabular}

Key: $\mathrm{SD}=$ Standard Deviation; $\mathrm{df}=$ Degree of freedom; $\mathrm{t}$-cal = calculated $\mathrm{t}$-value;

Sig. = Significance; $\mathrm{s}=$ significant

Table 7. T-test on difference in academic performance in biology based on type of school

\begin{tabular}{|c|c|c|c|c|c|c|}
\hline Group & $\begin{array}{l}\text { Grade } \\
\text { Average }\end{array}$ & Score & SD & $\mathrm{df}$ & t-cal. & Sig. of t-value \\
\hline Boarding & 2.45 & & .86 & 3127 & -19.96 & $0.00(\mathrm{~s})$ \\
\hline Day & 3.25 & & .90 & & & \\
\hline
\end{tabular}

Key: $\mathrm{SD}=$ Standard Deviation; $\mathrm{df}=$ Degree of freedom; $\mathrm{t}-\mathrm{cal}=$ calculated $\mathrm{t}$-value;

Sig. $=$ Significance; $\mathrm{s}=$ significant

Table 8. T-test on difference in academic performance in biology based on school location

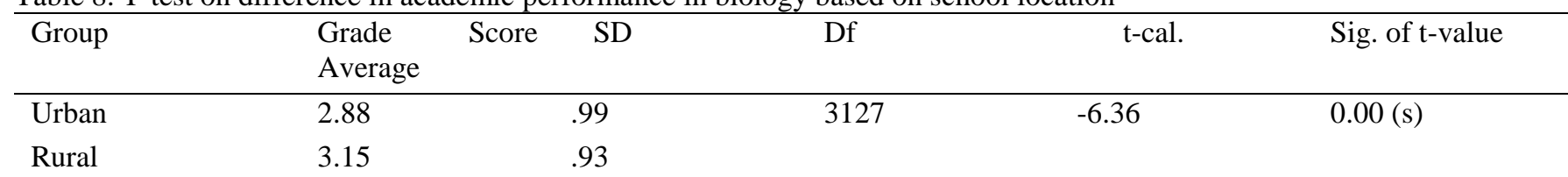

Key: $\mathrm{SD}=$ Standard Deviation; $\mathrm{df}=$ Degree of freedom; $\mathrm{t}-\mathrm{cal}=$ calculated $\mathrm{t}-\mathrm{value} ;$ Sig.$=$ Significance; $\mathrm{s}=$ significant

The difference between the performance of male and female students in biology in favor of male students can be attributed to gender stereotyping which encourages both male and female students to show interest in the school subjects related to the role that society confirms them (Rwegasira, 2017). Also, most of the time, girls are involved in extracurricular activities such as domestic chores than boys (Bizimana, 2011). Therefore, after school, boys can have time to complete assigned tasks by biology teachers, resulting in better academic performance than girls.

To study whether the students' performance in the Biology National Examination is governed by the type of school, the average Biology grade scores of boarding and day students were used to conduct a test of difference using the independent sample t-test. The findings of the test are presented in Table 7.

Table 7 indicates that boarding school students on the grade score average performed better than the day school students $(\mathrm{t}=-19.96, \mathrm{df}=3127, \mathrm{p}<.05)$. This denotes that boarding school students performed better than day school students. This finding agrees with the findings of Adetunde, (2009), Bard (2011), Adebisi et al. (2017), and Ogechukwu and Chika (2018). The significant difference between the performance of boarding and day students in favor of boarding schools maybe because most boarding secondary schools in Rwanda admit the best performers in Primary 6 National Exams. Those who perform poorly are denied access to public boarding or government-aided ordinary level schools due to government resource constraints (World Bank, 2011; Nizeyimana \& Nkiliye, 2015). Day secondary schools, therefore, attract a significant proportion of less performing students who want to follow secondary education.

Besides, boarding school students are most of the time under the control of school management, unlike day school students who are distracted at home by household chores. This corroborates with Bard (2011); Nizeyimana and Nkiliye (2015); Ogechukwu and Chika (2018) who opined that day students are distracted at home unlike boarding students that are under the control of their teachers and as such are kept in control during their studies. Besides, day school teachers' career dissatisfaction resulting from low government salaries without the top-up from parents may contribute to the low performance of day school students. This is in agreement with Oredein and Awodun (2012) whose study findings revealed a significant relationship between regular payment of teachers' allowance and academic performance of science students in Nigeria. The findings of Nizeyimana and Nkiliye (2015), Mbonyumuvunyi (2015), Muhire (2015) in Rwanda also support the study findings that boarding schools performed better than day schools because they enjoy adequate facilities than day schools.

To identify whether the difference in students' performance in Biology National Examination based on school location is significant, the grade score average of urban school students and rural school students were used to conduct a test of difference using the independent sample t-test, as presented in Table 8 .

The results in Table 8 show that boarding school students on the grade score average were statistically and significantly better $(\mathrm{t}=-6.36, \mathrm{df}=3127, \mathrm{p}<.05)$. The urban school students performed better than the rural school 
students. This finding on school location still is in line with that of Olutola (2017), Umar (2017), Bichi et al. (2019) in Biology. Similarly, there was a significant difference between the academic performance of students in rural and urban secondary schools in Basic Science in favor of urban school students (Awodun \& Oyeniyi, 2018). A significant difference between urban school students and rural school students was equally reported in students' academic performance in the English language (Ellah \& Ita, 2017). Besides, Alordiah et al. (2015) reported it Mathematics, as well as Agriculture by Ugwuoke et al. (2019). In these studies, the urban school students were reported to outperform better than the rural school students. However, the finding of this study negates that of Mafulul (2012), Sharma (2016) which did not find a significant difference in the academic performance of students in urban and rural schools.

The significant difference observed in the performance of students from urban and rural schools in favor of urban school students may be explained by the fact that urban school students were exposed to different social amenities and instructional materials which manifested their better performance than students from rural areas where the social amenities and instructional materials may not be available or are inadequate. This is in agreement with Umar (2017) and Ugwuoke et al. (2019) who uphold the view that students in urban areas enjoy a favorable school environment with educational facilities that promote the teaching and learning process, thus thereby brings about the observed disparity in the performance of students in Biology. Also, urban school students may have performed better than the rural students as results of qualified teachers wanting to post to urban schools, unlike rural schools where qualified teachers refuse to post.

\section{CONCLUSION, IMPLICATIONS, RECOMMENDATIONS}

AND

The findings of this study revealed that the students' academic performance in Biology National Examination is not satisfactory as the majority of them (49\%) obtained a 9-grade score indicating a complete failure. There was a significant difference in students' academic performance in Biology based on gender, school type, and school location. In this regard, the results revealed that male students performed better than their female counterparts. The results indicated that boarding school students performed better than the students from day schools, and urban school students performed better than the rural school students did. Therefore, the study concludes that gender, type of school, and school location affect students' academic performance in Biology National Examination.

The reasoning drawn from the literature corroborates with the findings from the present study. Some suggestions that could have implications for educational policymakers include:

- There should be policy formulation that will ensure adequate provision for both human, financial, and teaching and learning materials, both boarding and day schools

- The biology teachers need more orientation on the Biology Competence-Based Curriculum as well as more supervision and support on a regular basis to equip them with sufficient knowledge and skills for effective, and efficient implementation of BCBC.

In light of the findings from this study, special attention should be given to students' gender, type of school, and school location as follows:

- Biology teachers could intensify their efforts to encourage female students to show more interest in science in general and biology particularly, irrespective of type and school location; to help them build their confidence in the subject.

- The parents can be made aware so that they try to make their homes conducive to learning and provide the necessary instructional materials that would help their children do self-study at home.

- The government and its partners in education should bridge the gap between the urban and the rural areas in terms of infrastructural amenities including wellequipped schools, adequate staffing with qualified and well-motivated personnel, and physical facilities to attract teachers in rural areas.

Implementing the above recommendations should lead to the improvement of students' performance. However, further studies should be carried out to find out to which extent different factors others than those considered in this study, affect students' performance in biology and implement appropriate strategies. These factors include but not limited to biology teacher training, teaching methods and strategies, teachers' and students' attitudes towards biology, students' family socioeconomic status, and so on.

\section{ACKNOWLEDGEMENTS}

This study was achieved with financial support from ACEITLMS and was conducted with the approval of Nyamagabe district, Rwanda. Thanks go to the District Director of Education and the District Education Officer in charge of secondary schools. Thanks to Dr. Philothere NTAWIHA, Mr. Emmanuel NIYIBIZI, and Mrs. Catherine DAY for their comments on this study. Thanks to Mrs. Fortunée UWIZEYIMANA and Mr. Emmanuel MURWANASHYAKA for their encouragement.

\section{REFERENCES}

Adebisi, M.A, Nkechi, E.O, \& Danmole, B.T. (2017). Comparison of boarding and day senior secondary school students' performance in Biology in Owo, Ondo 
State, Nigeria. Asia Pacific Journal of Education, Arts, and Sciences, 4(3), 45-50.

Adetunde, A. I, \& Asare, B. (2009). Comparative performance of day and boarding students in secondary school certificate mathematics examinations: A case study of Kasena-Nankana and Asuogyaman Districts of Ghana. Academia Arena, 1(4), 7-10.

Alordiah, C. O., Akpadaka, G., \& Oviogbodu, C. O. (2015). The influence of gender, school location, and socio-economic status on students' academic achievement in mathematics. Journal of Education and Practice, 6(17), 130-136.

Atieno, L. (2017, November 7). Why parents opt for boarding schools? The New Times.

http://www.newtimes.co.rw

Awodun, A. O., \& Oyeniyi, A. D. (2018). Influence of school location 'on students' academic achievement in junior secondary school basic science in Ekiti State, Nigeria. Journal of Emerging Technologies and Innovative Research, 5(2), 23-27.

Bagabe, P.M. (2015). English language proficiency and students' performance in secondary schools in $R$ wanda. A case study of Bugesera district [Master's thesis]. http://umispace.umi.ac.ug/handle/20.500.12305/146

Bard, N. (2011). In-put out formation on the academic achievement of a learner. Maxwell.

Bennel, P., \& Ntagaramba, J. (2008). Teacher motivation and incentives in Rwanda: Situational analysis and recommended priority actions. Kigali Rwanda Education NGO Cooperation Platform.

http://www.rencp.org/wpcontent/uploads/2010/06/Teacher-Motivation-andIncentives-in-Rwanda-08.doc

Bichi, A.A., Fatima, B. I., \& Rahinatu, H. I. (2019). Assessment of students' performances in biology: Implication for measurements and evaluation of learning. Journal of Education and Learning (EduLearn), 13(3), 301-308.

https://doi.org/10.11591/edulearn.v13i3.12200

Biggs, J. (1996). Enhancing teaching through constructive alignment. Higher Education, 32(3), 347-364. https://doi.org/10.1007/bf00138871

Bizimana, E. (2011). Analysis of factors affecting girls' access to education in selected secondary schools in Huye district, Rwanda [Unpublished master's thesis]. Kampala International University.

Bozdoğan, A. E., Günaydın, E., \& Okur, A. (2014). An examination of secondary school students' academic achievement in science course and achievement scores in performance assignments concerning different variables: A boarding school example. Participatory Educational Research, 1(2), 95-105.

https://doi.org/10.17275/per.14.13.1.2

Byusa, E., Kampire, E., \& Mwesigye, A. R. (2020). Analysis of teaching techniques and scheme of work in teaching chemistry in Rwandan secondary schools. Eurasia Journal of Mathematics, Science and Technology Education, 16(6). https://doi.org/10.29333/ejmste/7833
Creswell, J. W. (2014). Research design: Qualitative, quantitative, and mixed methods approach (4th ed.). SAGE.

Ellah, K. E., \& Ita, P. M. (2017). Correlational relationship between school location and students' academic performance in the English language in Nigerian secondary schools. International Journal of Scientific and Research Publications, 7(9), 381-384.

Harerimana, J.P., M. H., Ntahobavukira, B., M. A., \& Toyin, A.O. (2017). In-service education programmes for secondary school teachers and students' academic performance: A case study of Nyarugenge district in Rwanda. IOSR Journal of Humanities and Social Science, 22(2), 100-115. https://doi.org/10.9790/0837220205100115

Kashu, J. N. (2014). Survey on gender and academic performance in secondary schools in Kenya [Unpublished master's thesis]. University of Nairobi.

Lackamp, J.W. (2016). Case Study - results at primary school-leaving examination in a rural district in Rwanda. International Journal of Learning, Teaching and Educational Research, 15(9), 99-117.

Mafulul, M.J. (2012). School location versus academic achievement in physics: Does computer-assisted instruction (CAI) has any effect? Journal of Educational and Social Research, 2(8), 162-168. https://doi.org/10.5901/jesr.2012.v2n8p162

Mbarushimana, N., \& Kuboja, J.M. (2016). A paradigm shift towards competence-based curriculum: The experience of Rwanda. Saudi Journal of Business and Management Studies, 1(1), 6-17.

Mbonyumuvunyi, A. (2015). School management strategies and students' academic performance in secondary schools in Rwanda: A case study of Nyamagabe district [Unpublished master's thesis]. Mount Kenya University, Kigali, Rwanda.

Ministry of Education. (2007). Teacher development and management policy in Rwanda. MINEDUC, Kigali. www.reb.rw

Ministry of Education. (2012). 2013 Education statistics yearbook. MINEDUC, Kigali, Rwanda. www.MINEDUC.gov.rw

Muhire, P. (2015). Teaching Facilities and Students' Academic Performance in Secondary Schools of Nyamagabe District, Rwanda [Unpublished master's thesis]. Mount Kenya University.

National Curriculum Development Centre (2006). Ordinary level science curriculum (biology, chemistry, physics). Kigali: Ministry of Education.

Ndihokubwayo, K. (2017). Research on improvised experiment materials for science lessons in Rwanda [Unpublished master's thesis]. Hiroshima University, Japan.

Ngendahayo, E., \& Askell-Williams, H., (2016). Publishing higher degree research. Accessed on 16 October 2020 at https://doi.org/10.1007/978-94-6300672-9F

Ngozi, I.D., Anyanwu, R. I., Bitrus, Z., Dalhatu, H., \& Folashade, S. (2018). Comparative study of the academic performances in Biology, Chemistry, and 
Physics of male and female students in a Nigerian tertiary institution. Journal of Education and Practice, 9(20), 68-76.

Nizeyimana, G., \& Nkiriye, I. (2015). A baseline survey on barriers to quality of basic education in Rwanda: The case study of Kicukiro, Gicumbi, and Rwamagana districts (Final Report, March 2015). Rwanda Education for All Coalition.

Nkurunziza, J., Broekhuis, A., \& Hooimeijer, P. (2012). Free education in Rwanda: Just one step towards reducing gender and sibling inequalities. Education Research International, 2012, 1-11. https://doi.org/10.1155/2012/396019

Nnenna, G.E., \& Adukwu, B. C. (2018). Influence of gender and school location on senior secondary school students' achievement in Biology Inagbani Education Zone of Enugu State, Nigeria. Journal of Education and Practice, 9(21), 45-51.

Nsengimana, T., Habimana, S., \& Mutarutinya, V. (2017). Mathematics and science teachers ' understanding and practices of learner-centered education in nine secondary schools from three districts in Rwanda. Rwandan Journal of Education, 4(1), 55-68.

Ntawiha, P. (2016). Educational Inputs and their implications for output in public secondary schools in Nyarugenge and Nyamasheke districts, Rwanda [Unpublished doctoral dissertation]. Kenyatta

Nzabalirwa, W., \& Nkiliye, I. (2012). A study on the socio-economic conditions of teachers in primary and secondary public schools in Rwanda: A case study of Bugesera, Nyarugenge, and Ruhango Districts. Rwandan Journal of Education, 1(1), 72-83.

Ogbianigene, P. D. (2014). Effect of gender on students' academic achievement in secondary school social studies. Journal of Education and Practice, 5(21), 7885.

Ogechukwu, O. F., \& Chika, N. P. (2018). The extent of academic achievement of day and boarding secondary school students in Anambra State, Nigeria. International Journal of Scientific Research and Management, 6(1), 20-26.

https://doi.org/10.18535/ijsrm/v6i1.el03

Okorie, E.U, O., \& Ezeh, D.N. N. (2016). Influence of gender and location on students' achievement in chemical bonding. Mediterranean Journal of Social Sciences, 7(3), 309-318. https://doi.org/10.5901/mjss.2016.v7n3p309

Olasehinde, K. J., \& Olatoye, R. A. (2014). Comparison of male and female senior secondary school students' learning outcomes in science in Katsina state, Nigeria. Mediterranean Journal of Social Sciences. https://doi.org/10.5901/mjss.2014.v5n2p517

Olusola, R., \& Omotade, A. (2014). Impact of school location on academic achievement of science students in senior secondary school certificate examination. International Journal of Scientific and Research Publications, 4(9), 4-7.

Olutola, A. T. (2017). School location and gender as predictors of students' performance in WASSCE multiple-choice test in biology. Liceo Journal of
Higher Education Research, 12(1), 11-20.

https://doi.org/10.7828/ljher.v12i1.960

Orbanić, N. D., Dimec, D. S., \& Cencič, M. (2016). The effectiveness of a constructivist teaching model on students' understanding of photosynthesis. Journal of Baltic Science Education, 15(5), 575-587.

Oredein, A., \& Awodun, A. (2012). Impact of teachers' motivational indices on science students' academic performance in Nigerian senior secondary schools. International Education Studies, 6(2), 49-54. https://doi.org/10.5539/ies.v6n2p49

Parajuli, M., \& Thapa, A. (2017). Gender differences in the academic performance of students. Journal of Development and Social Engineering, 3(1), 39-47. https://doi.org/10.3126/jdse.v3i1.27958

Pearson, P. (2014). Policy without a plan: English as a medium of instruction in Rwanda. Current Issues in Language Planning, 15(1), 39-56. https://doi.org/10.1080/14664208.2013.857286

Rubagiza, J., Umutoni, J., \& Kaleeba, A. (2016). Teachers as agents of change: Promoting peacebuilding and social cohesion in schools in Rwanda. Education as Change, 20(3), 202-224. https://doi.org/10.17159/1947-9417/2016/1533

Rwanda Education Board. (2015). Ordinary level mathematics and science syllabi. Kigali, Rwanda. Rwanda Education Board.

Rwanda Education Board. (2013). Eligibility, rules, and regulations for private candidates intending to sit for advanced level secondary school National Examinations.

Rwegasira, E.M. (2017). Factors influencing girl's poor academic performance in community secondary schools: The case of Kishapu district [Unpublished master's thesis]. Mzumbe University.

Sharma, G. (2016). Locale and sex as determinants of academic performance. International Journal of Information Research and Review, 3(8), 2691-2694. http://www.ijirr.com/sites/default/files/issuesfiles/1260_0.pdf

Sibomana, E. (2014). The acquisition of English as a second language. Rwandan Journal of Education, 2(2), 19-30.

Tumwebaze, P. (2016, July 6). Performance: Why distance to school matters. The New Times. http://www.newtimes.co.rw

Ugwuoke U., Emeka Eze, \& Anene Omeje. (2019). The impact of home background and locality on the secondary school students' academic performance in agriculture in Enugu state, Nigeria. Journal of Education Research and Evaluation, 2(4), 156. https://doi.org/10.23887/jere.v2i4.15530

Umar, O. J. (2017). A Comparative study of facilities and students' performances in Biology in urban and rural schools: A case study of Adavi Local Government Area of Kogi State. International Journal of Education and Evaluation, 3(6), 1-6.

UNESCO. (2014). Teaching and learning: Achieving quality for all. EFA Global Monitoring Report 2013/2014. 
World Bank. (2011). Rwanda Education country status report toward quality enhancement and achievement of universal nine years of basic education. An education system in transition, a nation in transition.

www.worldbank.org 